\title{
John Aage Gjestrums TRYCKTA SKRIFTER
}

Per-Uno Agren

Bibliografin är sammanställd på grundval av listor ställda till förfogande av John Aage Gjestrums hustru Elisabeth Nordengen samt en publikationslista som John Aage själv upprättat 1992. Titlarna är ordnade i huvudgrupperna Bøker, Artikler (med undergrupperna Arboka TOTN, Museumsnytt, Nordisk Museologi och Øvrige artikler), Plandokumenter och Foredrag. Inom varje grupp redovisas titlarna kronologiskt.

\section{BøKER}

1984

Gards-og slektshistorie. En studie av 170 bokmeldinger av gards-og slektshistoriske bygdebøker i tidsskriftet Heimen. Gjøvik. Totens Bokhandel.

\section{5}

Muntlig historie i det museale arbeidsfelt. Telemark distriktshøgskole, Kulturarbeiderstudiet. Ved katalog til Toten Museums lydbåndarkiv, båndsidene 1-100. $50 \mathrm{~s}$.

1987

Landskapet på vestsida av Mjosa. 1837-1987. Jubileumsbok utgitt av Gjensidige Vestoppland. Gjøvik.

Økomuseumsboka - identitet, økologi, deltakelse. Red. J.A.G. og Marc Maure, Norsk ICOM. Tromsø. 1991

Visjon og virke. Johannes Sivesind 70 år. Red. J.A.G. Utkom som Årboka TOTN 1991.

\section{Artikle R}

1. Årboka TOTN (redaktør 1978-1991) 1976

"Sæterhus på Toten", s. 186-200.

1977

"Ta vare på gamle fotografier", s. 296-300.

1978

"Hågår gård til Toten museum", s. 362-366.

1979

"Jernbanebebyggelse og stasjonsbyer. Søkelys på århundreskiftets arkitektur og lokalhistorie", s. 14-21.

"Et virkelig godt bilde skal tåle å henge opp ned", s. 22-29. Intervju med Ingvar Heggsum.

"Gjøa-bua". (Lokalt sagnstoff), s. 30-32.

"Ach, wie fluctig, ach, wie wichtig. Hofforglet på

Norsk Folkemuseum klinger igjen", s. 55-57.

"Det eldste Totenpostkort", s. 77.

1980

"Skoleminner fra 1880-åra: 100-årige Marie Stangjordet forteller", s. 30-33. 
"Søkelys på arbeiderkulturen. Arbeiderbilder fra Raufoss", s. 78-87.

"Verneprosjektet Ytre Amunddalen", s. 132-137.

\section{1}

"Kulturlandskap, museum og bygningsvern", s. 7-13.

"Stenberg - museum i 50 år", s. 38-49.

"Bygningen", s.118-132.

1982

"Gjenstandene i museumsarbeidet: Skal vi samle på kunst, antikviteter eller skrap?”, s. 48-55.

\section{3}

"Tolv totninger forteller", s. 6-7.

\section{4}

"Totenkniven - husflid, småindustri og kunsthåndverk", s. 6-46.

"Turist på Hadeland og Toten i 1784", s. 101-110.

"Hoff Arbeidersamfunn", s. 114-117.

\section{5}

"1900-tallet - snart forrige århundre. Økomuseet

- et bindeledd mellom fortid, nåtid og framtid", s. $6-15$.

"Fra 9. mai til 9. juni. Billedserie fra HS-gruppa på

Raufoss", s. 30-43.

\section{6}

"Skreia jernbanestasjon - en perle som jernbanehistorie og miljø”, s. 6-31.

"Taarene rand ved efter kindene paa hannem. Om husmann og bonde på Toten i 1712", s. 63-64.

"Tre husmannskontrakter fra 1800-tallet", s. 65-71.

1987

"Innledning til Jens Raabe: En storbygd", s. 6-11.

\section{8}

"Hovedbygningen fra Raufoss gård blir en del av økomuseet", s. 86-95.

"Ny kilde oppdaget: Da fyrstikkfabrikken ble bygget”, s. 107-117.

"Ingen lek, men arbeid og slit! Industrielt barnearbeid på Raufoss 1875-1895”, s. 118-126. Denne artikkelen er tidligere trykt i Ophedia 1982.
"Petra Jensen bodde "i bolin", s. 127-130.

1990

"Økomuseet - for lokalsamfunnet i verden", s. 6-15.

"Einar Hermanrud (1893-1981) forteller historie",

$$
\text { s. } 76-105 \text {. }
$$

1991

"Visjon og virke - Johannes Sivesind 70 år". (J.A.G. red.)

\section{Museumsnytt (redaktør 1989-1991)}

\section{2}

"Opplandsmuseene mot år 2000: om en start på arbeidet med 1900-tall og samtidsdokumentasjon i Oppland." Nr 3, s. 14-17.

1983

"Regionmuseet: Et bærende element i norsk museumsvesen?" $\mathrm{Nr} 3$, s. 11-14.

1984

"Seminaret: økologi og identitet - økomuseumstanken har slått rot i Norge”. Nr 2.

1985

"Fra vikingmelk til industrikultursenter". $\mathrm{Nr} 1$.

"Museene og industrisamfunnet", fra en rapport ved Roy Høibo, Jone Johnsen og Torleif Lindtveit. (Sammenfatning ved J.A.G.) Nr 2.

"Museer også for 2000-tallets mennesker". Nr 3-4.

1987

"Musea og opplysningsorganisasjonane: Samarbeid under utvikling." Nr 3-4, s. 30-31.

\section{8}

"Norske museer - problemer uten løsninger? En oppsummering av Trondheimskonferansen". Nr 1, s. 66-70.

1989

"Istedet for museumsbygg? Økomuseet - det åpne museet". Nr 1-2, s. 48-52.

"Fra 80-tall til 90-tall" (lederartikkel)". Nr 4, s. 3.

"Alle museer er historie om sosialhistorie" (Kenneth Hudson). Nr 3, s. 24-25. 
98 "ICOMs generalkonferanse i Haag ble en suksess".

Nr 3, s. 26-27.

"70-tall, 80-tall og 90-tall." Intervju med to formenn

(Per Hvamstad, Christian Andersen). Nr 4, s. 4.

"Fartøyvernet i Norge seiler i medvind". Nr 4, s. 8-11.

1990

"Terskler og visjoner" (lederartikkel). Nr 1, s. 3.

"Et nytt museum: $\AA$ i Lofoten". Nr 1, s. 4-11.

"Botanikk og politikk. Professor Olav Gjærevoll i intervju”. Nr 1, s. 20-25.

"Søkelys på Norsk Folkemuseum" (lederartikkel). $\mathrm{Nr} 2$, s. 2.

"Norsk Folkemuseum: 4 direktører 1994-1990 - ved to av dem". Nr 2, s. 4-12.

"Min interesse for museer er vekket gjennom kunsten. Kronprinsesse Sonja åpner MUSEUM 1990". Nr 2, s. 2-3.

"Jeg fant, jeg fant" (lederartikkel). Nr 3, s. 2-3.

"Støtt ICOM" (lederartikkel). Nr 4, s. 4.

"Fra Norge til Afrika og hjem". Nr 4, s. 4-9.

"Spredning av økologisk kunnskap" (intervju med

Bo Nilsson). Nr 4, s. 22-24.

\section{1}

"Om myter og virkelighet" (lederartikkel). Nr 1, s. 3.

"90-åra: Museene har fått en god start - intervju med fem museumsledere". Nr 1, s. 4-14.

"Norsk Fiskeindustrimuseum etableres på Melbu". Nr 1, s. 19-21.

"Museene og det nysgjerringe mennesket" (lederartikkel). Nr 2, s. 3.

"Museumspedagogikk på dagsorden i 15 år" (intervju med Svein Norheim). Nr 2, s. 23-25.

"Å kunne eller ikke kunne" (lederartikkel). Nr 3-4, s. 3.

"Et nytt nasjonalt kompetansesenter for museene kommer". Nr 3-4, s. 4-9.

"Ikke ødelegg båtene og båtbyggertradisjonen" (Gunnar Eldjarn i intervju). Nr 3-4.

"ICOM '95 - nå har vi $31 / 2$ år og gjøre det på"

(Karin Hellandsjø i intervju). Nr 3-4, s. 33-35.
1992

"Cuzals - museet som leker med tiden og rommet".

(Ved J.A.G., Torbjørn Eggen og Marc Maure)

$\mathrm{Nr}$ 1, s. 18-23.

"Big Bang i museumsverdenen". Nr 4, s. 26-28.

1993

"Museums-mænd og deres skidne tøi: Museumsforbundet ble til for å forsone central- og lokalmuseer". Nr 2, s. 4-15.

3. Nordisk Museologi (redaktør 1993-2000)

1993

”Anmälan”. (J.A.G. Ole Strandgaard og P.-U. Ågren)

\section{4}

"Lokalmuseer og museumsprofesjonalitet". Nr 1, s. 75-82.

1995

"A hundred texts on Nordic Museums in Museum".

Nr 2, s. 203-208.

1996

"En bibliografi om økomuseer" Nr 2, s. 57-70.

1999

"The Ecomuseum in Theory and Practice. The first

Chinese Ecomuseum established". (Ved An

Laishun og J.A.G.) Nr 2, s. 65-86.

Notiser signerade J.A.G. i 1993/1, 1994/2, 1995/1, 1996/1, 2, 1997/1, 1999/1, 2.

\section{4. Øvrige artikler}

1980

"Arbeiderbolig åpnet på Toten Museum”. Fakkelen, nr 7, s. 23-24.

\section{2}

"Fotografiet som sosialhistorisk dokument. Bildene dokumenterer!" Norsk fotohistorisk årbok 1981/82.

\section{5}

"Totentreff - et samarbeidsprosjekt museum og voksenopplæring 1976-1985”. Studienytt 6-7.

1986

"Toten Museum; an open-air museum on devolution 
to an ecomuseum", report from MINOMs 3.

International Workshop at Toten, Norway 1986.

"The ecomuseums in Norway", report from

MINOMs 3. International Workshop at Toten,

Norway.

«Nouvelle muséologie, traditions et perspectives nordiques - du musée de plein-air à l'écomusée/ les minorités des régions arctiques. 3e Atelier international de nouvelle muséologie, Toten». (Ved J.A.G. og Marc Maure) MINOM. 66 p. "Ecomuseums in Norway". ICOM's 14th Gerneral Conference in Buenos Aires, Argentina. ICR International Committee for Regional Museums.

\section{8}

"Økomuseer i Norge" i: Økomuseumsboka - identitet, økologi, deltakelse, (ved J.A.G og Maure, Marc) 1988, s.138-146.

"Museene mot år 2000" i: Økomuseumsboka - identitet, økologi, deltakelse, (ved J.A.G og Maure, Marc) 1988, s. 12-15.

"Museums as an instrument of community development”. ICOM-ICR Working Conference in Vladimir-Suzdal, USSR.

\section{9}

"Arbeiderkulturen på museum”. (Ved J.A.G. og Marc

Maure). Syn og Segn, nr 2, s. 157-164.

\section{0}

Dagfinn Slettan (red) "Kulturvernet møter 90-åra:

Toten Museum - økomuseum og lokalhistorisk senter". Presentasjon av museet og intervju med John Aage Gjestrum. Heimen 1990/2 s. 66-78.

"The ecomuseum - good news in Africa?"

ICOFOM: Museum and heritage preservation,

Zambia, Zambia Heritage News Magazine, 1990.

1992

"Økomuseumsperspektivet - en viktig innfallsvinkel og utfordring i den norske museumssituasjonen." I: Nymark, Lis og John Reshaur: Rapport fra Nordisk Økomuseumsseminar Samsø, 1992, s. 47-61.
1993

"Fra folkemuseum til økomuseum. Økomuseumsbegrepet - en fornyelse av museumsinstitusjonen og et viktig instrument for lokalsamfunnet". Heimen 1993/1, s. 30-45.

"Momenter for en drøfting av lokalmuseer i 90-tallets svenske museumsbilde. Vil 2000-tallet bli lokalmuseets hundreår?" 1993. Artikkelen er skrevet for Kommunala museers samarbetsråd, og er merket med "ikke for offentliggjøring". 28 sider.

\section{5}

"Norwegian experiences in the field of ecomuseums and museum decentralisation." (Schärer, Martin R. ed.) Symposium Museum and Community II, Stavanger, Norway July 1995. ICOFOM Study Series Vol. 25, s. 201-212.

"Utstilling av levende mennesker. En historie om samisk kultur og fremmede blikk". DUGNAD, tidsskrift for Etnologi, 1995/1, s. 93-108.

"Eit museologisk perspektiv." Arbok for Bergen museum 1995. Bergen 1996.

1996

"Mangfald mellom realisme og utopi. En kommentar til NOU:7 Museum. Mangfald, minne, møtestad." (Kronikk) Konferanseavis, Norges museumsforbund, Stavanger. 1996.

\section{7}

"Kan vi verne et telefonnummer, Om å velge framtidas kulturarv". Fortidsvern 1997/4, s. 26-27.

\section{Plandokumenter}

1988

Museumsutdanning i Norge: En norsk museumshøgskole. Utarbeidet for styret i NKKM (Norske Kunst- og Kulturhistoriske museer). $21 \mathrm{~s}$.

\section{2}

"Norsk fjellmuseum. Realisering og perspektiver." Arbeidsdokument. $47 \mathrm{~s}$. 
"Kommunala Museers Samarbetsråd. En förstudie om lokale/kommunale museer i det svenske museumsbildet." $54 \mathrm{~s}$.

1995

"Nasjonalt kulturbygg - Ivar Aasen-tunet". Revidert plandokument. $25 \mathrm{~s}$.

1996

"Dokumentasjonssenter - Ivar Aasen-tunet". Utgreiing. $27 \mathrm{~s}$.

1997

"Heilskap, historikk, bygningar og kulturlandskap". Utgreiing. Inneholder historikk omkring Ivar Aasen-tunet.

"Jugendsenteret - en nasjonal institusjon". (Ved J.A.G. og Marc Maure) Ålesund. Forprosjektdokument. 87 s. Del I: utgangspunkt for jugendsenter, - en ny type institusjon. - nasjonalt og internasjonalt perspektiv. Del II: Innhold.

Del III: Løsninger.

1998

"Rondane informasjonssenter". Forprosjektdokument. 49 s.

John Aage Gjestrums publikationslista 1992 upptar ytterligare ca 50 titlar från åren 19721992. Det är oklart om de finns publicerade. De avser bidrag till seminarier, möten framträdanden i skolor och föreningar, utredningar och notater för Toten museum. Många behandlar ekomuseifrågor, samtidsdokumentation, lokalmuseer, arkiv och publikationer. År 1983 talar han om "det integrerte museet, museet som nærsamfunnets historieverksted" under ett seminarium i Norsk Sjøfartsmuseum. Den mångårige medarbetaren Arne Julsrud Berg har framhållit John Aages betydelse
"Mjøssamlingene - struktur og utvikling 1993-98". $35 \mathrm{~s}$.

En utredning om videre utvikling og organisering av Mjøssamlingene.

"Antikvarisk bygningsbank. Forprosjekt." $42 \mathrm{~s}$. Planlegging av antikvarisk bygningsbank på Toten. Innledningskapitlet inneholder perspektiver som: - tenke globalt, handle lokalt, - fra avfall til kulturarv.

1999

"Industri- og arbeidermuseum. Gamle Holmen Brænderi, Gjøvik.” Forprosjekt. 53 s. Kapittel 1, Introduksjon og strategisk utgangspunkt, kan leses som en artikkel som tar opp betydningen av å ta vare på arbeiderkulturen. (Dette museumsprosjektet ble senere stoppet).

"Kapp Melkefabrikk: Utviklingsplan." 62 s. Viktig dokument. Kapittel 1 og 2 handler om perspektivene og historikken, og kan leses som artikler.

"Ivar Aasen-tunet. Utstillingsplan - basisutstilling." $35 \mathrm{~s}$.

även för publikationer som inte direkt bär hans namn. Totens Bygdebok, bind 4, av SveinErik Ødegaard (1984) "ble trendsetter for den nye genren av bygdebøker i Norge. ... John Aage laget modellen, layout, billedredaktør og hadde hele prosjektledelsen ned til minste detalj... Dette var uten tvil hans største bokprosjekt”. Motsvarande insats gjorde han för Berg-Nordsveens Damp-og motorbàter på Mjøsa (1996). Han var "redaktør for Mjøsa årbok (1982-83) og Mjøsa (1984-86) utgitt av museet Mjøssamlingene der han var styreformann." 